\title{
Pheochromocytoma with Hypertensive Crisis Caused by Endoscopic Ultrasound-guided Tissue Sampling
}

\author{
Hyo Hoon $\mathrm{Kim}^{1}$, Chang Min $\mathrm{Cho}^{1}$, Seong Jae $\mathrm{Yeo}^{1}$, Hyung Jun Kwon ${ }^{2}$, Seung Hyun $\mathrm{Cho}^{3}$, An Na Seo ${ }^{4}$ \\ Departments of Internal Medicine, ${ }^{2}$ Surgery, ${ }^{3}$ Radiology, and ${ }^{4}$ Pathology, School of Medicine, Kyungpook National University, Daegu, Korea
}

Although pheochromocytoma usually presents as a solid tumor, it can also present as a cystic lesion in the adrenal glands. Cystic lesions in the adrenal glands, along with hypertension, need attention to exclude pheochromocytoma. If ignored, they may lead to a hypertensive crisis with multi-organ failure. Proper preoperative preparation is important to prevent a hypertensive crisis during and after surgery. We report a case of pheochromocytoma with cystic degeneration that presented as a hypertensive crisis caused by endoscopic ultrasound-guided tissue sampling.

Korean J Pancreas Biliary Tract 2019;24(3):127-132

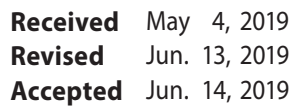

Received May 4, 2019

Revised Jun. 13, 2019

Accepted Jun. 14, 2019

Corresponding author : Chang Min Cho

Center for Pancreatobiliary Tumors, Kyungpook National University Chilgok Hospital, 807 Hokuk-ro, Buk-gu, Daegu 41404, Korea

Tel. +82-53-200-2608 Fax. +82-53-200-2028 E-mail; cmcho@knu.ac.kr

ORCID: https://orcid.org/0000-0002-9903-1282

Keywords: Pheochromocytoma, Hypertension, Fine needle biopsy, Endosonography

\section{INTRODUCTION}

Pheochromocytoma and paraganglioma are uncommon neuroendocrine neoplasms arising from chromaffin cells of the adrenal medulla and sympathetic ganglia, respectively. Although both tumors may be asymptomatic, they can present with headaches, sweating, palpitations, and paroxysmal hypertension. Sometimes, hypertensive crisis can lead to cardiomyopathy, pulmonary edema, and even total circulatory collapse.
We present a case of pheochromocytoma with hypertensive crisis that occurred after endoscopic ultrasound-guided tissue sampling (EUS-TS) for a cystic mass located at the retroperitoneum.

\section{CASE}

A 36-year-old man with a history of dry cough for a month was referred to Kyungpook National University Chilgok 
Hospital for the evaluation of a retroperitoneal mass, which was found incidentally on transabdominal ultrasonography. He had no specific past and family history and did not experience palpitations or a headache. He drank hardly, and smoked a pack of a cigarette a day. His initial vital signs were unremarkable: blood pressure of $117 / 77 \mathrm{mmHg}$, pulse rate of 88 beats per minute, respiratory rate of 18 breaths per minute, and body temperature of $36.5^{\circ} \mathrm{C}$. Laboratory findings including complete blood counts, liver function, electrolytes, and tumor markers were within normal range. Abdominal computed tomography showed a well-enhanced round mass measuring $5 \mathrm{~cm}$ located in the left pararenal space (Fig. 1A). The mass had central cystic degeneration and was abutting the left crus (Fig. 1B). Endoscopic ultrasound (EUS) was performed under conscious sedation with meperidine, midazolam and propofol and demonstrated a well-defined heterogeneous retroperitoneal
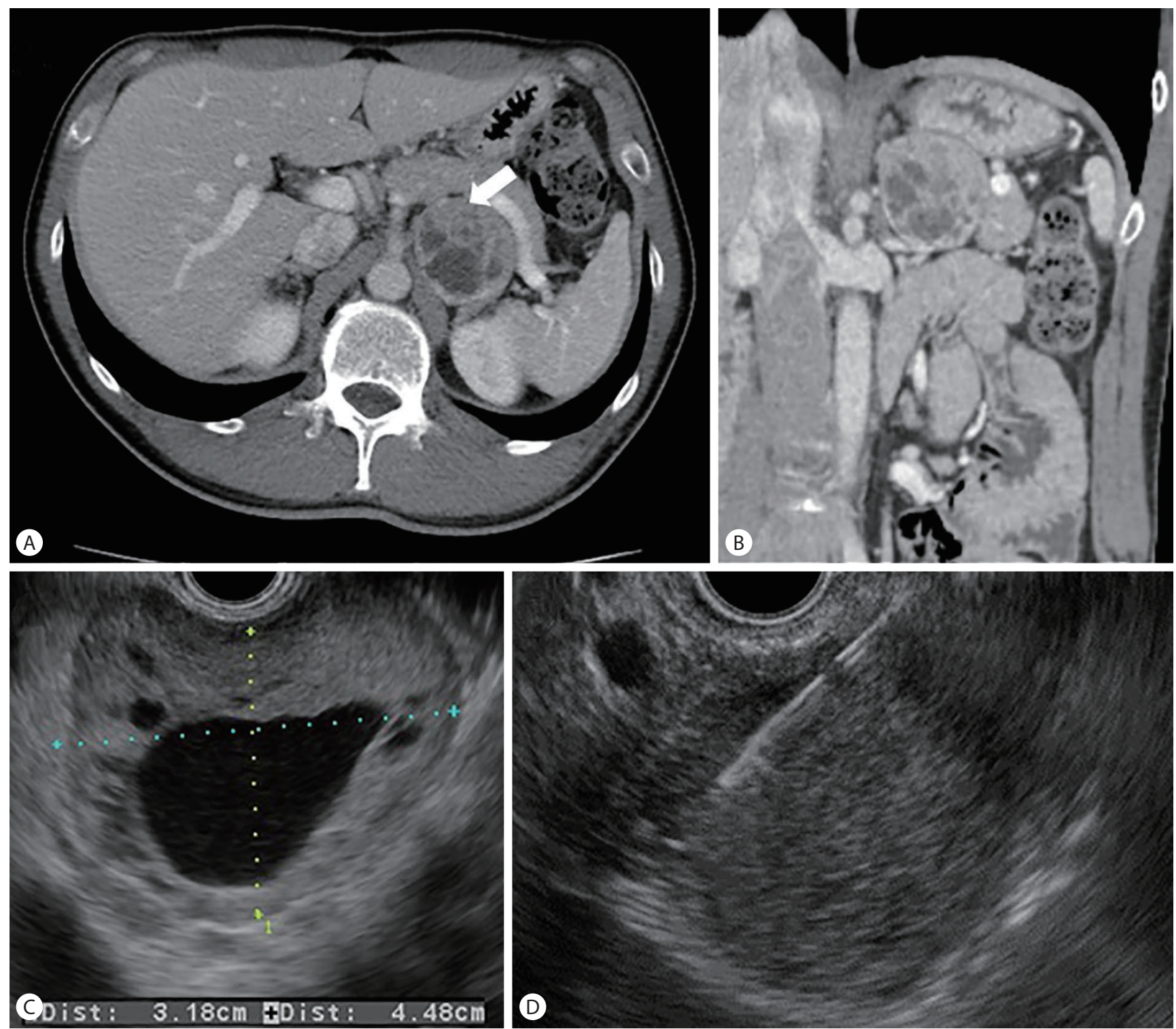

Fig. 1. Abdominal computed tomography demonstrated a well-enhanced round mass measuring $5 \mathrm{~cm}$ located in the left pararenal space (arrow) (A). The mass had central cystic degeneration and was abutting the left crus (B). Endoscopic ultrasound revealed a well-defined heterogeneous retroperitoneal mass with anechoic cystic lesions (C). Endoscopic ultrasound-guided fine-needle biopsy was performed twice using a 20-gauge needle (ProCore, Cook Medical, Winston Salem, IN, USA) (D). 
mass with anechoic cystic lesions (Fig. 1C). To exclude malignancy and to confirm histological diagnosis of the lesion, EUS-guided fine-needle biopsy was performed not by liquid part but in solid part. Biopsy was performed twice with a 20-gauge needle (ProCore; Cook Medical, Winston Salem, IN, USA) (Fig. 1D). After the procedure, he complained of a headache in the recovery room. Since that time, persistent elevations in blood pressure $(186 / 112 \mathrm{mmHg})$ were checked. Thereafter, the patient's clinical conditions progressively deteriorated for 12 hours with the development of symptoms including chest tightness, cough with blood-tinged sputum, breathing difficulty, and oliguria. Chest X-ray showed bilateral perihilar haziness in both lung fields (Fig. 2). Laboratory findings showed elevations in cardiac enzymes such as creatine kinase-MB isoenzyme $(259.4 \mathrm{ng} / \mathrm{mL})$ and troponin I (>50.0 $\mathrm{ng} / \mathrm{mL}$ ), azotemia (serum creatinine of $3.82 \mathrm{mg} / \mathrm{dL}$ ), and acidosis $(\mathrm{pH}, 7.25)$. Electrocardiography demonstrated elevation in the ST segment at precordial leads. Vital parameters showed a blood pressure of $155 / 100 \mathrm{mmHg}$, pulse rate of 129 beats per minute, respiratory rate of 29 breaths per minute, and oxygen saturation of $73 \%$ at room air. Despite supplying oxygen, the $\mathrm{O}_{2}$ saturation was $85-88 \%$. The patient was immediately admitted to the intensive care unit with a provi-

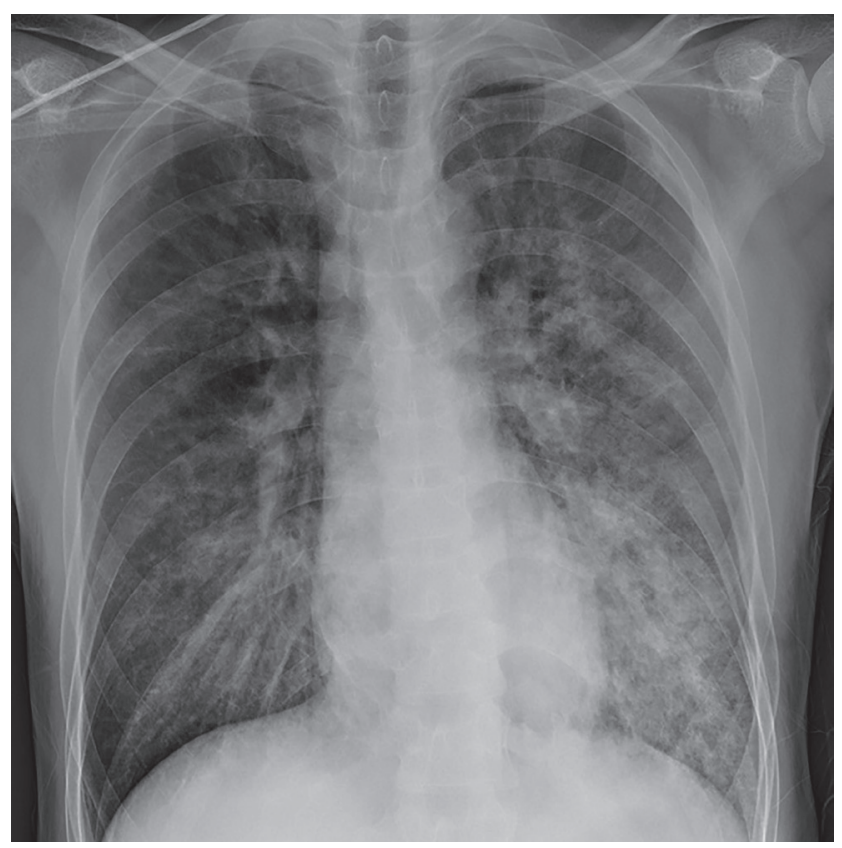

Fig. 2. Chest X-ray of posteroanterior view showed pulmonary edema. sional diagnosis of a hypertensive crisis and secondary acute decompensated organ failure. $\mathrm{O}_{2}$ supply, intravenous diuretics, and an alpha-adrenergic blocker were administered. Thereafter, the symptoms associated with pulmonary edema, cardiac dysfunction, and azotemia slowly improved for 48 hours without intubation, and he was discharged 10 days after EUS-TS. The histological diagnosis of EUS-TS was paraganglioma; Immunohistochemical staining revealed positive for chromogranin and synaptophysin and negative for CK19 and CK7. Later, the collected 24-hour urine data showed an epinephrine level of $41.68 \mu \mathrm{g} /$ day (reference, $<40 \mu \mathrm{g} /$ day), norepinephrine level of $222.49 \mu \mathrm{g} /$ day $(<80 \mu \mathrm{g} /$ day), vanillylmandelic acid (VMA) level of $16.4 \mathrm{mg} /$ day ( $<8 \mathrm{mg} /$ day), and metanephrine level of $2.93 \mathrm{mg} /$ day $(<0.8 \mathrm{mg} /$ day $)$.

Surgical resection was performed 6 weeks later without complications. In the surgical field, the mass was located between the pancreas body/tail and left adrenal gland. Histopathologic evaluation of the resected specimen demonstrated a huge solid mass with intralesional cystic degenerative changes. Also, the mass was abutting the left adrenal gland (Fig. 3A). Microscopically, the cells had abundant granular and vacuolated cytoplasm, with an occasional intracytoplasmic pink granule (Fig. 3B). The nuclei were vesicular and fairly uniform with occasional multinucleation. These histopathologic features are characteristics of pheochromocytoma, which was further confirmed by positive immunohistochemical staining for $\mathrm{S} 100$ protein (Fig. 3C) and synaptophysin (Fig. 3D). One year later, he was doing well without recurrence since resection.

\section{DISCUSSION}

Catecholamine-secreting tumors, which arise from chromaffin cells of the adrenal medulla and sympathetic ganglia, are referred to as pheochromocytoma and paraganglioma according to the origin of the tumor, respectively. ${ }^{1,2}$ Pheochromocytoma and paraganglioma are rare tumors with an incidence of approximately 1-2/100,000. Among the cases of pheochromocytoma, $10 \%$ are located in extra-adrenal areas. Due to the low prevalence of pheochromocytoma and its often nonspecific signs and symptoms, diagnosis is often delayed. 

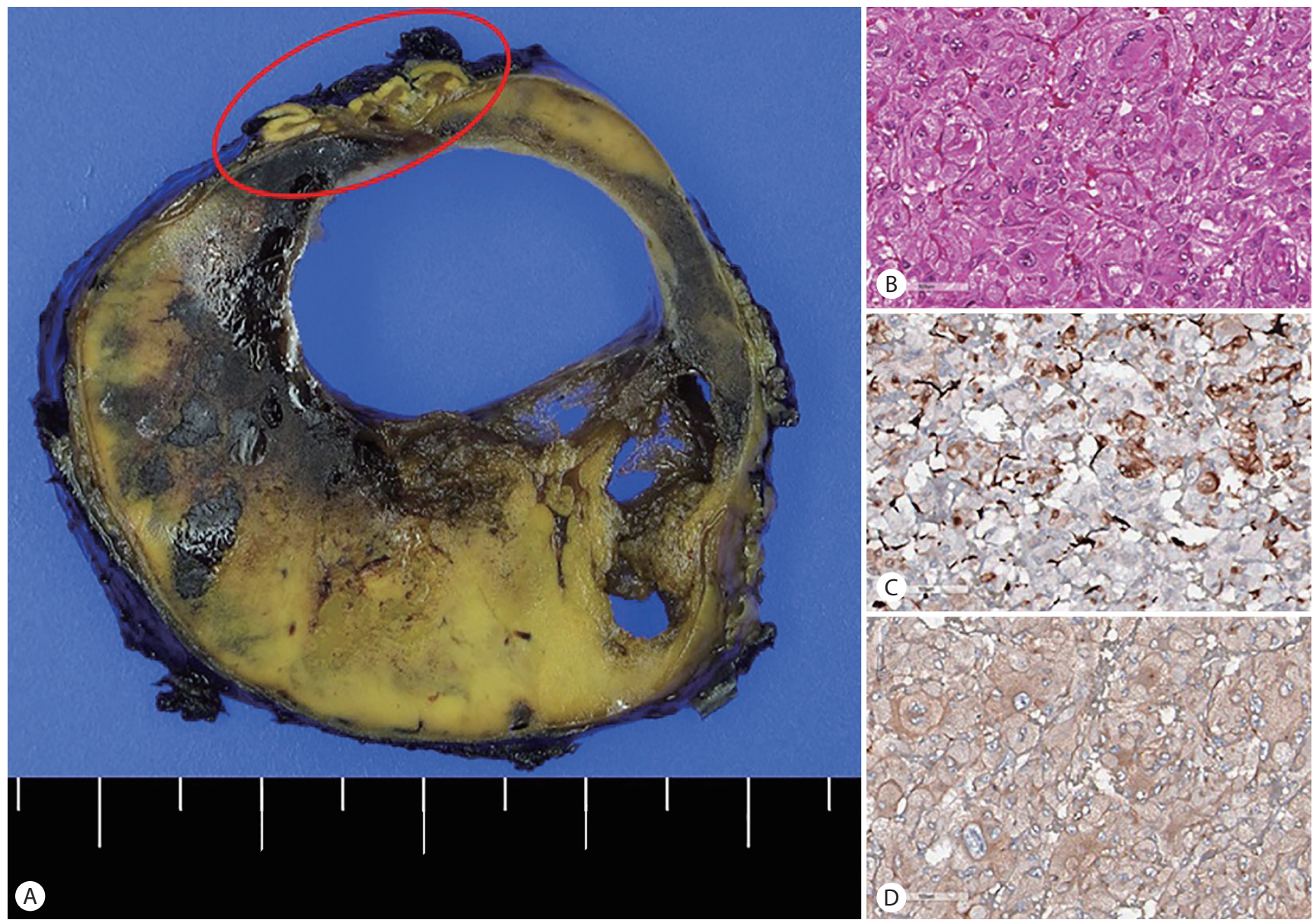

Fig. 3. Gross and microscopic findings of the resected specimen. (A) Gross finding demonstrated a huge solid mass with intralesional cystic degenerative changes, which was abutting the left adrenal gland (red circle). (B) Microscopically, the cells had abundant granular and vacuolated cytoplasm, with an occasional intracytoplasmic pink granule and the nuclei were vesicular and fairly uniform, with occasional multinucleation (hematoxylin and eosin staining, $\times 200)$. (C, D) Immunohistochemical staining showed positive for S100 protein ( $\times 200)$ and synaptophysin ( $\times 200)$.

Chromaffin cells produce, store, and secrete catecholamines: epinephrine, norepinephrine, and dopamine. In these two tumors, if epinephrine, norepinephrine, or their metabolites are elevated and the patient exhibits typical symptoms such as hypertension, it is classified as a hyperfunctioning tumor. Although abdominal paraganglioma tumors account for a smaller proportion of functional tumors than pheochromocytoma, preoperative treatment and control of blood pressure during surgery are very important, like in cases of pheochromocytoma. ${ }^{3}$

The diagnosis of pheochromocytoma is based on measuring excessive amounts of catecholamines and their metabolites in urine or plasma. Biochemical tests for catecholamine-secreting tumors typically use 24-hour urinary excretion measurements of total metanephrine and catecholamines. ${ }^{4-6}$ Over $90 \%$ of patients with pheochromocytoma have increased levels of catecholamines, metanephrine, and VMA. The sensitivity and specificity of 24-hour urinary VMA and metanephrines are $87.5 \%$ and $99.7 \%$, respectively. ${ }^{6}$

As described in the present case that involved an asymptomatic incidental cystic mass in the left retroperitoneum, pheochromocytoma and paraganglioma should be included in the differential diagnosis of a retroperitoneal mass based on EUS, particularly if the mass contains cystic lesions. Sometimes biochemical analysis may not be helpful, since cystic lesions can show normal urinary metanephrine and normetanephrine levels. Fortunately, for the patient of this case, metanephrine was elevated, which helped the diagnosis. In a report of the 
analysis of 31 patients with pheochromocytoma by Andreoni et al. ${ }^{8}$, six patients had cystic pheochromocytoma and three of them were asymptomatic. Cyst formation in pheochromocytoma might be due to intralesional hemorrhage, necrosis, and later cyst formation. Patients with cystic pheochromocytoma are more likely to be asymptomatic and tend to have a negative biochemical evaluation. ${ }^{9}$

Pheochromocytoma can present as cystic lesions, which may mislead the diagnosis and should be considered in patients with nonspecific symptoms and an incidental cystic adrenal mass, even in the absence of hypertension. ${ }^{10,11}$ Although a solid adrenal mass can be easily diagnosed with available diagnostic methods, it is difficult to diagnose cystic lesions since they structurally resemble benign adrenal cysts, which may be inconclusive in conventional images. Functional imaging, such as meta-iodobenzylguanidine (MIBG) scan, is essential to confirm the presence of chromaffin cells.

The classic triad of pheochromocytoma includes severe headaches, palpitations, and diaphoresis. Depending on its capacity to release catecholamines to the systemic circulation, pheochromocytoma may evoke mild or nonspecific signs and symptoms, and as a consequence, up to $15 \%$ of tumors remain undiagnosed during a patient's life. ${ }^{10,12}$ Therefore, the diagnosis may be unanticipated at the time of EUS-TS.

EUS-TS of retroperitoneal lesions and enlarged lymph nodes is safe and accurate. Adrenal and paraganglioma lesions can be included among lesions that can be obtained by EUS-TS. Although EUS-TS of an adrenal mass without any adverse events has been described in small numbers in case series, our case showed that EUS-guided puncture of a retroperitoneal mass may evoke an abrupt release of catecholamines, and subsequently, a life-threatening hypertensive crisis, similar to the well-known risk of percutaneous biopsy. Based on this case, we advise the exclusion of subclinical pheochromocytoma before performing EUS-TS of retroperitoneal lesions, even though the lesion may contain cysts.

The single most specific and reliable generic neuroendocrine marker currently used in pathology practice is chromogranin A $(\mathrm{CgA})$, a major constituent of the matrix of catecholaminecontaining secretory granules. ${ }^{13}$ Immunoreactivity for CgA will readily distinguish pheochromocytomas and other paragangliomas from tumors that are not neuroendocrine, such as those of the adrenal cortex. Pheochromocytoma and paragangliomas are stained for CgA, synaptophysin (also present in adrenal cortical carcinomas), and S100 protein.

This case demonstrated the risk of EUS-TS when paragangliomas and pheochromocytomas are not completely excluded in the retroperitoneal mass. In addition to 24-hour urinary excretion measurements of total metanephrine and catecholamines or screening tests with the measurement of plasmafractionated metanephrine, functional imaging like MIBG scans will be clearly able to define the etiology in cases of pheochromocytoma. ${ }^{9}$

In conclusion, pheochromocytoma or paraganglioma should be considered in patients presenting with nonspecific symptoms and an incidental cystic mass in retroperitoneal lesions, even in the absence of hypertension. We need to preoperatively treat and control blood pressure during EUS-TS and surgery.

\section{요 약}

부신에서 기원하는 종양 중 갈색세포종은 일반적으로 고형 병변으로 발현되지만, 드물게 낭성 병변으로 발견되는 경우도 있다. 고혈압과 동반된 부신의 낭성 병변에 대해서 갈색세포종을 감별 진단으로 포함시킬 필요가 있으며, 이를 간과할 경우 다발성 장기 부전을 동반하는 고혈압 위기를 초래할 수 있다. 수술 전후에 있어 적절한 조치가 고혈압성 위기를 예방하는 데 있어 중요하다. 저자들은 부신 낭성 부신 병변에 대한 초음파 내시경 유도하 조직 검사로 인하여 유발된 고혈압성 위기가 발생한 갈색세포종 증례를 경험하여 문헌고찰과 함께 보고하는 바이다.

국문 색인: 갈색세포종, 고혈압, 세침 바늘 생검, 초음파 내시경

\section{Conflicts of Interest}

The authors have no conflicts to disclose.

\section{REFERENCES}

1. Greenleaf CE, Griffin LA, Shake JG, Orr WS. Hypertensive crisis 
secondary to pheochromocytoma. Proc (Bayl Univ Med Cent) 2017:30:314-315.

2. Tischler AS. Pheochromocytoma and extra-adrenal paraganglioma: updates. Arch Pathol Lab Med 2008;132:1272-1284.

3. Benn DE, Gimenez-Roqueplo AP, Reilly JR, et al. Clinical presentation and penetrance of pheochromocytoma/paraganglioma syndromes. J Clin Endocrinol Metab 2006;91:827-836.

4. Kudva YC, Sawka AM, Young WF Jr. Clinical review 164: the laboratory diagnosis of adrenal pheochromocytoma: the Mayo Clinic experience. J Clin Endocrinol Metab 2003;88:4533-4539.

5. Perry CG, Sawka AM, Singh R, Thabane L, Bajnarek J, Young WF Jr. The diagnostic efficacy of urinary fractionated metanephrines measured by tandem mass spectrometry in detection of pheochromocytoma. Clin Endocrinol (Oxf) 2007;66:703-708.

6. Sawka AM, Jaeschke R, Singh RJ, Young WF Jr. A comparison of biochemical tests for pheochromocytoma: measurement of fractionated plasma metanephrines compared with the combination of 24-hour urinary metanephrines and catecholamines. J Clin Endocrinol Metab 2003;88:553-558.

7. Royaee AR, Hammamieh R, Mendis C, Das R, Jett M, Yang DC. Induction of immunomodulator transcriptional responses by cholera toxin.
Mol Immunol 2006;43:1020-1028.

8. Andreoni C, Krebs RK, Bruna PC, et al. Cystic phaeochromocytoma is a distinctive subgroup with special clinical, imaging and histological features that might mislead the diagnosis. BJU Int 2008;101:345-350.

9. Abdulsalam MS, Ganapathy V, Satish P, Janakiraman RK, Singh S. Cystic pheochromocytoma presenting as adrenal cyst. J Clin Diagn Res 2016;10:0D09-OD10.

10. Mannelli M, Lenders JW, Pacak K, Parenti G, Eisenhofer G. Subclinical phaeochromocytoma. Best Pract Res Clin Endocrinol Metab 2012;26:507-515.

11. Erem C, Kocak M, Onder Ersoz H, Ersoz S, Yucel Y. Epinephrinesecreting cystic pheochromocytoma presenting with an incidental adrenal mass: a case report and a review of the literature. Endocrine 2005;28:225-230.

12. Vanderveen KA, Thompson SM, Callstrom MR, et al. Biopsy of pheochromocytomas and paragangliomas: potential for disaster. Surgery 2009;146:1158-1166.

13. Feldman SA, Eiden LE. The chromogranins: their roles in secretion from neuroendocrine cells and as markers for neuroendocrine neoplasia. Endocr Pathol 2003;14:3-23. 